\title{
ABSTRAK \\ HUBUNGAN RIWAYAT PEMBERIAN ASI EKSKLUSIF DENGAN \\ KEJADIAN DIARE AKUT PADA ANAK DI RSUP PROF DR. R. D. KANDOU
}

\author{
${ }^{1}$ Tuti Jatiningrum Ibrahim \\ ${ }^{2}$ Jeannette I. Ch. Manoppo \\ ${ }^{3}$ Johnny Rompis

\begin{abstract}
Bagian Ilmu Kesehatan AnakFakultas Kedokteran Universitas Sam Ratulangi
Email: djatiningroem@yahoo.co.id
\end{abstract}

Background - The breast milk has higher nutrient value. Because of the antibody contained in the breast milk, the leucocytes, enzymes, and hormones will protect the baby from infections. Babies who were breastfed from childbirth to several months after will be protected from any kinds of infections, whether they are caused by the bacteria, viruses, or other antigens. In the developing countries, babies who were not given the exclusive breastfeed from the age of 0 to 5 months and no breastfed from the age of 6 to 23 months could raise the risk of morbidity and mortality caused by diarrhea. In Indonesia, diarrhea is still the second of 10 most common diseases in the population on the primary health care.

Objective - To find out the relations between exclusive breastfeeding history and the incidence of acute diarrhea on children in Prof. Dr. R. D. Kandou Hospital, Manado.

Methods - This research is an observational analytic study with cross sectional approach, done in the Department of Pediatric of Prof. Dr. R. D. Kandou Hospital, Manado from November to December 2013. The subject of the experiment is around 100 children age 6 months to 5 years old and classified into 50 children with acute diarrhea and 50 children as the control group. The data are gathered using questionnaires given to the parents of the subjects and analyzed using the chi square.

Results - From 100 children as the subject, in 44 children with exclusive breastfeeding history there are 16 children with diarrhea and 28 without diarrhea. Meanwhile, in the remaining 56 children without history of exclusive breastfeeding, 34 children are infected with diarrhea and 22 are not infected. The value of the significance result is $\mathrm{p}<0.05$ with significance value of 0.016 means significant.

Conclusion - There is a significant relation between exclusive breastfeeding history and the incidence of acute diarrhea on children in Prof. Dr. R. D. Kandou Hospital, Manado.

Keywords :Exclusive breastfeeding, acute diarrhea on children.

Latar Belakang - ASI memiliki nilai gizi lebih tinggi, karena adanya antibodi pada ASI, selsel leukosit, enzim dan hormon akan melindungi bayi terhadap infeksi. Bayi yang mendapatkan ASI pada waktu lahir sampai beberapa bulan sesudahnya akan terlindungi dari berbagai macam infeksi, baik yang disebabkan oleh bakteri, virus dan antigen lainnya. Di negara berkembang, bayi yang tidak diberikan ASI eksklusif pada usia 0-5 bulan dan tidak mendapatkan ASI pada usia 6-23 bulan dapat meningkatkan risiko morbiditas dan mortalitas karena diare. Di Indonesia, diare masih menempati urutan kedua dalam urutan 10 penyakit terbanyak dipopulasi pada pelayanan kesehatan primer.

Tujuan - Mengetahui hubungan riwayat pemberian ASI eksklusif dengan kejadian diare akut pada anak di RSUP. Prof. Dr. R. D. Kandou Manado. 
Metode - Penelitian ini merupakan studi analitik observasional dengan pendekatan cross sectional, dilakukan di Bagian Ilmu Kesehatan Anak RSUP Prof. Dr. R. D. Kandou Manado selama bulan November - Desember 2013. Subyek penelitian sebanyak 100 anak berumur 6 bulan - 5 tahun dan dikelompokkan menjadi 50 anak diare akut dan 50 anak kelompok kontrol. Pengumpulan data menggunakan kuesioner kepada orangtua subyek penelitian.Data dianalisis dengan chi square.

Hasil-Subyek penelitian berjumlah 100 anak yang terdiri atas 44 anak dengan riwayat asi eksklusif yang terdiri dari 16 mengalami diare dan 28 tidak mengalami diare sedangkan 56 anak dengan riwayat tidak asi eksklusif yang terdiri dari 34 mengalami diare dan 22 tidak mengalami diare. Hasil signifikansi bernilai $\mathrm{p}<0.05$ dengan nilai signifikansi 0.016 yang berarti signifikan atau bermakna. $(\mathrm{p}=0,016)$

Kesimpulan - terdapat hubungan antara riwayat pemberian ASI eksklusif dengan kejadian diare akut pada Anak di RSUP Prof. DR. R. D. Kandou Manado.

Kata kunci :ASI eksklusif, diare akut pada anak.

\section{PENDAHULUAN}

Air Susu Ibu (ASI) sangat diperlukan selama masa pertumbuhan dan perkembangan bayi. ${ }^{1}$ Bayi yang mendapatkan ASI pada waktu lahir sampai beberapa bulan sesudahnya akan terlindungi dari berbagai macam infeksi, baik yang disebabkan oleh bakteri, virus dan antigen lainnya. ${ }^{2}$

Menurut WHO, menyusui eksklusif adalah tidak memberi bayi makanan atau minuman lain, termasuk air putih , selain menyusui (kecuali obat-obatan dan vitamin atau mineral tetes) sampai usia 6 bulan. Di seluruh negara, diperkirakan hanya sekitar 38\% bayi usia 0 - 6 bulan yang diberikan ASI eksklusif.,

Berdasarkan data Riset Kesehatan Dasar (Riskesdas) tahun 2010, persentase pola menyusui eksklusif pada bayi umur 0 bulan adalah 39,8 \%. Sedangkan pada bayi yang berumur 5 bulan menyusui eksklusif hanya 15,3\%. ${ }^{4}$ Menurut survei Indonesia Demographic and Health Survey (IDHS) tahun 2007, persentase menyusui eksklusif di Indonesia sebesar $32,3 \%$, dan di Sulewesi Utara sebesar 28,8\%. ${ }^{5}$

ASI memiliki nilai gizi lebih tinggi, karena adanya antibodi pada ASI, sel-sel leukosit, enzim dan hormon akan melindungi bayi terhadap infeksi. ${ }^{6}$ Penelitian oleh WHO membuktikan bahwa pemberian ASI sampai usia 2 tahun dapat menurunkan angka kematian anak akibat penyakit diare dan infeksi saluran napas akut. ${ }^{7}$

Di negara berkembang, bayi yang tidak diberikan ASI eksklusif pada usia 0-5 bulan dan tidak mendapatkan ASI pada usia 6-23 bulan dapat meningkatkan risiko morbiditas dan mortalitas karena diare. ${ }^{8}$ Diare adalah penyakit yang ditandai dengan bertambahnya frekuensi defekasi lebih dari biasanya (>3 kali/hari) disertai perubahan konsistensi tinja (menjadi cair), dengan/tanpa darah dan/atau lendir. ${ }^{2}$ Di Indonesia, diare masih menempati urutan kedua dalam urutan 10 penyakit terbanyak dipopulasi pada pelayanan kesehatan primer. ${ }^{9}$

Sekitar 1,7 juta kasus diare terjadi setiap tahunnya, 760.000 anak dibawah usia 5 tahun meninggal tiap tahun karena diare. ${ }^{10}$ Di negara berkembang, rata - rata anak dibawah usia 3 tahun tiap tahunnya mengalami 3 kali kejadian diare. ${ }^{10}$ Berdasarkan Riset Kesehatan Dasar (Riskesdas) tahun 2007, penyebab kematian bayi (usia 29 hari - 11 bulan) yang terbanyak adalah diare (31,4\%) dan penyebab kematian anak balita usia (12-59 bulan) terbanyak juga adalah diare $(25,2 \%){ }^{11}$ 
Hasil Survei Morbiditas Diare tahun 2010, untuk angka kesakitan diare balita tahun 2000-2010 tidak menunjukkan pola kenaikan maupun pola penurunan (berfluktuasi). Pada tahun 2006 menjadi 1.330 per 1000 tahun kemudian turun pada 2010 menjadi 1.310 per 1000 tahun. ${ }^{12}$ Pasien diare yang di rawat-inap di Bangsal Gastroenterologi RS Prof. RD Kandou mulai Januari 2007 sampai Desember 2008 sebesar 201 anak. ${ }^{13}$

Berdasarkan uraian diatas peneliti ingin mengetahui apakah terdapat hubungan riwayat pemberian ASI eksklusif dengan kejadian diare akut pada anak.Tujuan penelitian ini adalah mengetahui hubungan riwayat pemberian ASI eksklusif dengan kejadian diare akut pada anak di RSUP. Prof. Dr. R. D. Kandou Manado.

\section{METODE PENELITIAN}

Penelitian ini dilakukan di Ruang Perawatan Anak bagian Ilmu Kesehatan Anak BLU RSUP Prof. Dr. R. D. Kandou Manado. Jenis penelitian ini adalah adalah studi analitik observasional dengan pendekatan cross sectional. Populasi penelitian ini adalah Populasi penelitian yaitu semua pasien anak di Ruang Perawatan Anak bagian Ilmu Kesehatan Anak BLU RSUP Prof. Dr. R.D. Kandou selama bulan November - Desember 2013.

Sampel penelitian adalah anak usia 6 bulan sampai dengan 5 tahun dengan diagnosa diare akut. Sampel diambil secara purposive sampling, kelompok anak diare ak ut berjumlah 50 orang dan kelompok kontrol berjumlah 50 orang. Variabel bebas yang diukur adalah riwayat ASI serta variabel terikatnya adalah diare akut.Pengumpulan data menggunakan kuesioner.Data dianalisis menggunakan uji Chi Square.

\section{HASIL}

Selama periode penelitian didapatkan 50 anak yang sesuai dengan kriteria inklusi peneliti. Diperoleh angka insidens 9,47\% dari 528 pasien anak di RSUP Prof.Dr. R. D. Kandou. Distribusi pasien diare akut tertera pada tabel 1.

Tabel 1.Distribusi pasien diare akut.

\begin{tabular}{cccc}
\hline Bulan & $\begin{array}{c}\text { Jumlah penderita } \\
\text { diare akut } \\
\text { (n) }\end{array}$ & $\begin{array}{c}\text { Jumlah seluruh } \\
\text { penderita anak } \\
(\mathbf{n})\end{array}$ & $\begin{array}{c}\text { Angka insidens } \\
\text { (\%) }\end{array}$ \\
\hline $\begin{array}{c}\text { November - } \\
\text { Desember } 2013\end{array}$ & 50 & 528 & 9,47 \\
\hline
\end{tabular}

Pada penelitian ini diperoleh pasien diare akut laki-laki (48\%) lebih sedikit dibandingkan perempuan (52\%).Distribus responden berdasarkan jenis kelamin dapat dilihat pada tabel 2. 
Tabel 2. Distribusi responden berdasarkan jenis kelamin

\begin{tabular}{ccccc}
\hline Jenis Kelamin & \multicolumn{2}{c}{ Diare Akut } & \multicolumn{2}{c}{ Tidak Diare } \\
& $\mathbf{n}$ & $\mathbf{\%}$ & $\mathbf{n}$ & $\mathbf{\%}$ \\
\hline Laki-laki & 24 & 48 & 20 & 40 \\
Perempuan & 26 & 52 & 30 & 60 \\
\hline Total & $\mathbf{5 0}$ & $\mathbf{1 0 0}$ & $\mathbf{5 0}$ & $\mathbf{1 0 0}$ \\
\hline
\end{tabular}

Diare akut paling banyak diderita anak berumur 12 bulan - 23 bulan (42\%).Distribusi responden berdasarkan umur dapat dilihat pada tabel 3.

Tabel 3. Distribusi responden berdasarkan umur

\begin{tabular}{ccccc}
\hline Umur & \multicolumn{2}{c}{ Diare Akut } & \multicolumn{2}{c}{ Tidak Diare } \\
\hline 6-11 bulan & 12 & 24 & 5 & n \\
\hline 12-23 bulan & 21 & 42 & 6 & 12 \\
24-35 bulan & 11 & 22 & 10 & 20 \\
36-47 bulan & 4 & 8 & 4 & 8 \\
$48-60$ bulan & 2 & 4 & 25 & 50 \\
\hline Total & $\mathbf{5 0}$ & $\mathbf{1 0 0}$ & $\mathbf{5 0}$ & $\mathbf{1 0 0}$ \\
\hline
\end{tabular}

Pada tabel 4 diketahui kejadian diare pada anak dengan riwayat eksklusif lebih rendah daripada anak dengan riwayat ASI tidak eksklusif (29\% vs $49 \%$ ).

Tabel 4. Distribusi responden berdasarkan kejadian diare

\begin{tabular}{ccccc}
\hline \multirow{2}{*}{ Riwayat ASI } & $\mathbf{0}$ kali & \multicolumn{3}{c}{ Kejadian Diare Akut } \\
& $\mathbf{1}$ kali & 2 kali & 3 kali \\
n (\%) & n (\%) & n (\%) \\
\hline ASI Eksklusif & $15(68,2)$ & $24(49)$ & $2(9,5)$ & $3(37,5)$ \\
Tidak ASI Eksklusif & $7(31,8)$ & $25(51)$ & $19(90,5)$ & $5(62,5)$ \\
\hline Total & $\mathbf{2 2 ( 1 0 0 )}$ & $\mathbf{4 9 ( 1 0 0 )}$ & $\mathbf{2 1 ( 1 0 0 )}$ & $\mathbf{8 ( 1 0 0 )}$ \\
\hline
\end{tabular}

Pada tabel 5 didapatkan anak kelompok diare akut yang diberikan ASI eksklusif sebesar 16 anak (32\%) sedangkan yang tidak memiliki riwayat ASI eksklusif sebesar 34 anak $(68 \%)$. 
Tabel 5. Distribusi responden berdasarkan riwayat ASI

\begin{tabular}{ccccccccc}
\hline \multirow{2}{*}{ Riwayat ASI } & \multicolumn{2}{c}{ Diare Akut } & \multicolumn{2}{c}{ Tidak Diare } & \multicolumn{2}{c}{ Total } & \multicolumn{2}{c}{ Uji X $\mathbf{X}^{2}$} \\
& $\mathbf{n}$ & $\mathbf{\%}$ & $\mathbf{n}$ & $\mathbf{\%}$ & $\mathbf{n}$ & $\mathbf{\%}$ & (p) \\
\hline ASI Eksklusif & 16 & 32 & 28 & 56 & 44 & 44 & 5,844 \\
& & & & & & & $(0.016)$ \\
Tidak ASI Eksklusif & 34 & 68 & 22 & 44 & 56 & 56 & \\
\hline Total & $\mathbf{5 0}$ & $\mathbf{1 0 0}$ & $\mathbf{5 0}$ & $\mathbf{1 0 0}$ & $\mathbf{1 0 0}$ & $\mathbf{1 0 0}$ & \\
\hline
\end{tabular}

Hasil uji chi square diperoleh nilai signifikan p-value sebesar 0.016 dan nilai chi square sebesar 5,844. Karena nilai signifikan $0.016<0.05$ maka nilai hipotesis null ditolak dan hipotesis alternatif diterima bahwa ada hubungan yang bermakna antara riwayat pemberian ASI eksklusif dengan kejadian diare.

\section{PEMBAHASAN}

Pada penelitian yang dilakukan selama bulan November - Desember 2013 didapatkan total sampel berjumlah 100 anak yang terdiri atas 50 anak kelompok diare akut dan 50 anak kelompok kontrol. Angka insidens pada bulan November - Desember 2013 didapatkan 9,47\% dari 528 pasien anak di ruang perawatan anak bagian Ilmu Kesehatan Anak RSUP Prof dr. R. D Kandou Manado.

Dari 50 anak penderita diare akut yang dirawat di ruang perawatan anak bagian Ilmu Kesehatan Anak RSUP Prof Dr. R. D. Kandou Manado yang sesuai dengan kriteria inklusi peneliti didapatkan 24 anak berjenis kelamin laki-laki dan 26 anak berjenis kelamin perempuan. Hal ini serupa dengan penelitian yang dilakukan oleh Yusuf ${ }^{14}$ pada tahun 2011 didapatkan prevalensi diare pada balita perempuan lebih tinggi sedikit dibanding balita lakilaki. Pada kasus tertentu jenis kelamin mempengaruhi terjadinya penyakit akan tetapi pada kasus diare jenis kelamin tidak mempengaruhi kejadian diare. ${ }^{14}$

Pada tabel 3 diperoleh jumlah sampel berdasarkan umur. Diketahui pada kelompok anak diare akut berumur 12 - 23 bulan paling banyak menderita diare akut sebanyak 21 anak atau 42\%, diikuti kelompok anak berumur 6 - 11 bulan sebanyak 12 anak (24\%). Penelitian yang dilakukan oleh Widowati $\mathrm{dkk}^{15}$ di Yogyakarta, didapatkan insidens tertinggi penderita diare pada usia 6 bulan - 2 tahun (85\%). Dalam studi yang dilakukan oleh Kadim dkk ${ }^{16}$ juga didapatkan insidens diare tertinggi 6 - 23 bulan (74\%). Penelitian di Bangladesh, Vietnam, Brazil, maupun negara-negara Eropa melaporkan prevalensi tertinggi diare rotavirus pada kelompok usia 6-23 bulan, kemudian menurun dengan bertambahnya umur. ${ }^{15}$ Angka kesakitan pada bayi dan anak berhubungan dengan daya tahan tubuhnya sehingga anak dan terutama bayi memiliki risiko yang lebih besar untuk menderita diare dibandingkan orang dewasa. ${ }^{14}$ Bayi kurang dari 6 bulan jarang menderita diare, diduga berhubungan dengan antibodi ibu yang disalurkan melalui air susu ibu, sedangkan anak lebih dari 23 bulan kemungkinan telah memiliki kekebalan alamiah yang mampu memberikan perlindungan pada infeksi berikutnya. ${ }^{16,17}$

Pada tabel 4 diketahui kejadian diare pada anak dengan riwayat eksklusif lebih rendah daripada anak dengan riwayat ASI tidak eksklusif (29\% vs 49\%). Studi di Nepal 
membuktikan anak yang tidak mendapatkan ASI berisiko mendapatkan diare 9 kali lipat dibandingkan dengan yang mendapatkan ASI. ${ }^{18} \mathrm{Hal}$ ini dikarenakan ASI mengandung sIgA, yang dihasilkan oleh sel dendritik intestinal dan dapat memberikan efek proteksi terhadap patogen. Selain itu ASI juga mengandung beberapa komponen antibodi lainnya. ${ }^{18}$

Pada tabel 5 didapatkan anak kelompok diare akut yang diberikan ASI eksklusif sebesar 16 anak (32\%) sedangkan yang tidak memiliki riwayat ASI eksklusif sebesar 34 anak (68\%). Dari tabel 5 diketahui hubungan pemberian ASI eksklusif dengan kejadian diare akut pada anak di RSUP Prof. Dr R. D. Kandou menunjukkan p-value sebesar 0.016 dan angka ini bersifat signifikan $(\mathrm{p}<0.05)$. Nilai ini menunjukkan adanya hubungan antara pemberian ASI eksklusif dengan kejadian diare akut.Studi oleh Ehlayel dkk $^{31}$ menyatakan bahwa risiko bayi non ASI ekslusif lebih tinggi dan signifikan dibandingkan bayi dengan ASI eksklusif (37.3\% vs $32.5 \%$, p <0.001). Diare dapat dicegah oleh beberapa faktor, salah satunya dengan pemberian ASI eksklusif. ${ }^{18-21}$

Berdasarkan studi Duijts $\mathrm{dkk}^{21}$, didapatkan hasil bahwa kejadian diare pada bayi yang tidak mendapat ASI eksklusif lebih tinggi dibandingkan dengan yang mendapat ASI eksklusif [aOR:0.65(95\% CI:0.51-0.83)]. Demikian pula studi kohort di Bangladesh, bayi yang mendapatkan ASI eksklusif selama 6 bulan memiliki prevalensi diare lebih rendah [aOR = 2.50 (95\% CI 1.10, 5.69) $\mathrm{p}=0.003$ ] daripada yang tidak ASI. $^{22}$

Pemberian ASI dapat juga mencegah diare, disebutkan oleh Tumbelaka ${ }^{7}$ bahwa berbagai faktor perlindungan ditemukan di dalam ASI, termasuk sIgA, yang akan berpengaruh terhadap paparan mikroorganisme pada saluran cerna bayi dan membatasi masuknya bakteri ke dalam aliran darah melalui mukosa saluran cerna.sIgA di dalam ASI dilaporkan memiliki aktivitas antibodi terhadap virus (Polio, Rotavirus, Echo, Coxsackie, Haemophilus influenzae, virus respiratori sinsisial/RSV), bakteri (Streptococcus pneumoniae; E. coli, Klebsiela, Shigela, Salmonela, Campylobacter), dan enterotoksin yang dikeluarkan oleh Vibrio cholerae, E. coli serta Giardia lamblia. Selain mengandung IgA, ASI juga mengandung epidermal growth factor (EGF) yang membantu proses maturasi dari epitel intestinal, IgA dan oligosakarida yang mencegah perlekatan bakteri patogen, serta laktoferin, suatu glikoprotein pengikat besi yang dapat melawan bakteri, virus dan jamur. ${ }^{18,21}$

Selain itu, dengan menyusui dapat mengurangi risiko terkena pajanan mikroorganisme penyebab diare yang mungkin mengkontaminasi susu formula, botol maupun peralatan makan. $^{17}$

\section{KESIMPULAN}

Berdasarkan penelitian yang telah dilakukan maka dapat disimpulkan bahwa terdapat hubungan antara riwayat pemberian ASI eksklusif dengan kejadian diare akut pada anak di RSUP Prof. Dr. R. D. Kandou.Pada anak dengan riwayat ASI eksklusif kejadian diare lebih rendah dibandingkan dengan anak dengan riwayat tidak ASI eksklusif.

\section{SARAN}

1. Bagi institusi kesehatan, perlu ditingkatkan penyuluhan dan sosialisasi kesehatan khususnya tentang manfaat ASI eksklusif selama 6 bulan dan dilanjutkan sampai usia 2 tahun. 
2. Dapat dilakukan penelitian lebih lanjut terhadap pengaruh ASI pada anak penderita diare dengan memperhatikan lama perawatan dan derajat dehidrasi.

3. Dapat dilakukan penelitian lebih lanjut mengenai faktor lain yang dapat mempengaruhi kejadian diare.

\section{DAFTAR PUSTAKA}

1. Aldy OS, Lubis MB, Sianturi P, Azlin E, Tjipta GD. Dampak air susu ibu terhadap infeksi. Sari Pediatri. 2009;11(3):167-73.

2. Suraatmaja, S. Diare. Dalam: Suraatmaja S, penyunting. Gastroenterologi Anak. Jakarta: CV. Sagung Seto; 2007.h.1-24.

3. WHO. Infant and young child feeding. 2013. diakses dari www.who.int/mediacentre/factsheets/fs342/en/(diakses tanggal 11 September 2013)

4. Kemenkes RI. Riset Kesehatan Dasar. 2010. diakses dari http://www.riskesdas.litbang.depkes.go.id/laporan2010/(diakses tanggal 5 September 2013)

5. United Nations Children's Fund. Child poverty and diparities in Indonesia.2012. diakses dari www.unicef.org/indonesia/ (diakses tanggal 22 September 2013)

6. Soetjiningsih. Peran ASI dalam pencegahan dan pengobatan diare akut. Dalam: Suraatmaja S, penyunting. Gastroenterologi Anak. Jakarta: CV. Sagung Seto;2007.h.77-83.

7. Tumbelaka AR, Karyanti MR. Air susu ibu dan pengendalian infeksi. Dalam: Hegar B, Suradi R, Hendarto A, Pratiwi IGA, penyunting. Bedah ASI. Jakarta: IDAI; 2008.h.83-97

8. Lamberti ML, Walker CLF, Noiman A, Victoria C, Black RE. Breastfeeding and the risk for diarrhea morbidity and mortality. BMC Public Health. 2011;11(3):S15

9. WHO. Diarrhoeal disease. 2013. Diakses dari www.who.int/mediacentre/factsheets/fs330/en/(diakses tanggal 11 September 2013)

10. Subagyo B, Santoso NB. Diare akut. Dalam: Juffrie M, Soenarto SSY, Oswari H, Arief S, Rosalina I, Mulyani NS, penyunting. Buku Ajar Gastroentero-Hepatologi. Cetakan ke-3. Jakarta : Badan Penerbit IDAI; 2012.h.87-102.

11. Kemenkes RI. Riset kesehatan dasar. 2007. diakses dari http://www.riskesdas.litbang.depkes.go.id/laporan2007/(diakses tanggal 5 September 2013)

12. Kemenkes RI. Situasi diare di Indonesia. Triwulan II;2011. diakses dari http://www.depkes.go.id/downloads/Buletin\%20Diare_Final(1).pdf(diakses tanggal 28 Agustus 2013)

13. Manoppo C.Dampak pemberian seng dan probiotik terhadap lama diare akut di RS Prof. DR. RD. Kandou Manado. Sari Pediatri. 2010;12(1):17-20.

14. Yusuf S. Profil diare di ruang rawat inap anak. Sari Pediatri. 2011;13(4):265-70.

15. Widowati T, Mulyani SN, Nirwati H, Soenarto Y. Diare rotavirus pada anak usia balita. Sari Pediatri. 2012;13(5):340-5.

16. Kadim M, Soenarto Y, Hegar B, Firmansyah A. Epidemiology of rotavirus diarrhea in children under Five: A hospital based surverillance in Jakarta. Paediatr Indones. 2011;51(3):138-43.

17. Pun SB. Rotavirus infection: an unrecognised disease in Nepal. Kathmandu. Univ Med J. 2010;8:135-40.

18. Ballard O, Morrow AL. Human milk composition. Pediatr Clin N Am. 2013;60:49-74.

19. Ehlayel SM, Bener A, Abdulrahman HM. Protective effect of breastfeeding on diarrhea among children in rapidly growing newly developed society. Turk J Pediatr. 2009;51:527-33.

20. Cairncross S, Hunt C, Boisson S, Bostoen K, Curtis V, Fung ICH, et al. Water, sanitation and hygiene for the prevention of diarrhea. Int J Epidemiol.2010;39:193-205. 
21. Duijts L, Jaddoe VWV, Hofman A, Moll AH. Prolonged and exclusive breastfeeding reduces the risk of infectious diseases in infancy. Pediatrics. 2010;126:e18-25.

22. Mihrshahi S, Oddy WH, Peat JK, Kabir I. Association between infant feeding patterns and diarrhoeal and respiratory illness: a cohort study in Chittagong, Bangladesh. Int Breastfeeding J. 2008:3:28. 